\title{
The Physical Interaction between Nucleotide-Binding Oligomerization Domain Containing 2 and Leucine-Rich Repeat Kinase 2
}

\author{
Ji-A Jung ${ }^{*}$ and Sangwook Park ${ }^{\dagger, * *}$ \\ Department of Biomedical Laboratory Science, College of Health and Nursing, \\ Kyungwoon University, Gumi 39160, Korea
}

\begin{abstract}
Recently, decades of robust researches on degenerative brain disorder have been highlighted on the interactive connection of gut and brain. In terms of inflammatory cytokine production, others have shown that Nucleotide-Binding Oligomerization Domain Containing 2 (NOD2) is involved with Leucine-Rich Repeat Kinase 2 (LRRK2). HEK293T cells were transiently co-transfected with Myc-tagged LRRK2 and Flag-tagged NOD2 and then followed by co-immunoprecipitation assay. In this study, we provide the novel finding of physical protein-protein interaction between NOD2 and LRRK2. G2019S variant has shown stronger interactions against NOD2 than those of wild type LRRK2. In an axis of NOD2-LRRK2 communication, it is believed to pave a new way in the understanding of the bidirectional molecular mechanism of brain disorder, including Parkinson's disease into gut inflammatory disease, including Crohn's disease.
\end{abstract}

Key Words: NOD2, Crohn's disease, LRRK2, Parkinson's disease, Protein-protein interaction

크론병(Crohn's disease, $\mathrm{CD}$ )은 장내 세균에 대한 비정 상적인 면역반응을 나타내는 질병으로써 장관전체를 침 범할 수 있고 회장과 대장에 주로 궤양성 병변을 일으키 는 치명적인 합병증으로 진행할 수 있는 염증성 장질환 이다. 이 질병은 초기면역에 관여하는 세포 내 수용체 인 Nucleotide-binding oligomerization domain-like receptors (NLRs) 수용체 중 Nucleotide-binding oligomerization domain containing 2 (NOD2)와 관련성이 높은 것으로 알려져 있 다(Ananthakrishnan et al., 2018). 전장유전체 연관(Genome Wide Association Study, GWAS) 분석에 의하면 파킨슨병 (Parkinson's disease, PD)과 크론병은 염증반응에 관여한다 는 공통점이 있다(Van Limbergen et al., 2009). 한편, 파킨슨 병은 중간 뇌의 흑색질(substantia nigra)이 소실되면서 생 겨나는 만성 진행성 중추신경계 질환이다. 임상증상은 미묘한 떨림증상에서 시작하여 팔과 목으로 진행되며 자
발적인 움직임이 어려워지게 되어 구부정한 자세와 종종 걸음 형태의 차는 듯 발을 끌면서 걷고 양 팔을 굽혀 몸 통에 붙이고 걷는 경향이 있다(Cummings, 1992). 파킨슨병 을 유발하는 유전자 중 하나인 Leucine-rich repeat kinase 2 (LRRK2)는 백인에게 주로 가족성 돌연변이(G2019S)를 일으켜 노인성 뇌신경질환을 유발시키는 것으로 잘 알려 져 있다(Rajput et al., 2006). 미세아교세포(microglial cell)는 뇌에 상주하는 면역세포이며 선천면역체계에서 손상된 세 포나 외부 미생물에 대한 선천면역 수용체의 역할을 한 다. 뇌의 미세환경을 순찰하며 신경발생 조절, 시냅스 리 모델링, 그리고 신경염증을 조절하는 데 필수적인 세포이 다(Cryan and Dinan, 2015). 미세아교세포의 기능장애는 여 러 신경 발달성 질환과 신경퇴화성 뇌 질환의 발생과 진 행에 관련되어 있다. 그러나, 미세아교세포의 활성에 영 향을 미치는 신호와 인자들에 대한 연구는 매우 미비하

Received: March 12, 2020 / Revised: March 17, 2020 / Accepted: March 21, 2020

* Graduate student, ${ }^{* *}$ Professor.

${ }^{\dagger}$ Corresponding author: Sangwook Park. Department of Biomedical Laboratory Science, College of Health and Nursing Kyungwoon University, Gumi 39160, Korea.

Tel: +82-54-479-1282, Fax:+82-54-479-1280, e-mail: spark367@ikw.ac.kr

(C) The Korean Society for Biomedical Laboratory Sciences. All rights reserved.

(2) This is an Open Access article distributed under the terms of the Creative Commons Attribution Non-Commercial License (http://creativecommons.org/licenses/by-nc/3.0/) which permits unrestricted non-commercial use, distribution, and reproduction in any medium, provided the original work is properly cited. 
다. 미세아교세포는 뇌의 국소 신호뿐만 아니라 위장관 등 말초신경으로부터 미주신경(vagus nerve)를 통해 신호 를 서로 교환한다. 최근 전임상 연구에 의하면, 장내 미 생물군(microbiome)이 미세아교세포의 성숙과 기능을 조 절하는 데 중요한 역할을 하고 있으며 변형된 미생물군 구성이 인간에게 미세아교세포 연관성 신경장애를 일으 킨다고 보고되었다(Gareau, 2014). 이는 장(gut)과 뇌(brain) 사이 미생물군이 매개되어 양방향 신호가 질병을 일으킬 수 있다는 것을 암시한다. NOD2는 p62/SQSTM1와 결합 하여 염증조절반응에 관여하는 것으로 알려져 있다(Park et al., 2013). 또한, p62/SQSTM1는 LRRK2를 신경세포 내 에서 자가포식을 통해 단백질을 소멸하는 것으로 알려져 있다(Park et al., 2016). 본 연구에서는 초기면역 수용체인 $\mathrm{NOD} 2$ 와 파킨슨유발 원인단백질 중 하나인 LRRK2가 서로 물리적으로 상호결합을 한다는 사실을 확인하였다. BioGRID $^{3.5}$ (https://thebiogrid.org/), IntAct (https://www.ebi.ac.uk /intact/) 등과 같은 단백질 결합 온라인 데이터베이스를 통해 새로운 결합단백질임을 재확인할 수 있었다. 공동면 역침강(Co-Immunoprecipitation, Co-IP)을 이용하여 단백질 과 단백질간의 결합여부를 알아보기 위해 소유하고 있는 Myc-tagged LRRK2 (Dr. Suh YH, Seoul National University, Korea)와 Myc-tagged NOD2 (Dr. Kufer T, University of Hohenheim, Germany)을 공동 과발현하기 전에 상대적으 로 단백질 크기가 작은 NOD2를 Flag fusion protein으로 교체(Flag-NOD2)하였다. 이를 위해 FLAG-CMV7.1 vector $(4.7 \mathrm{~kb})$ 에 제한효소 $(\mathrm{KpnI}, \mathrm{BamH \textrm {I }})$ 염기를 5' 끝단에 포함한 primer set (Myc-NOD2: Forward_KpnI: GGGGTACCAATGGGGGAAGAGGGTGGTT; Reverse_: BamHI: CGGGATCCTCAAAGCAAGAGTCTGGTGT)를 디자인하여 Myc-NOD2 를 표적핵산으로 Phusion ${ }^{\circledR}$ High-Fidelity DNA Polymerases (NEB, USA)를 이용하여 2단계 PCR 조건(pre-Denaturation, $98^{\circ} \mathrm{C}, 30$ 초간 1 회; Denaturation, $98^{\circ} \mathrm{C}, 5$ 초간 1 회; AnealingExtenstion, $72^{\circ} \mathrm{C}, 47$ 초간 35 회; Final Extension, $72^{\circ} \mathrm{C}, 5$ 분간 1 회) 조건에서 수행하였다. 발현백터에 클로닝하기 위해 증폭된 blunt end PCR products를 dA-tailing 과정과 $\mathrm{T}$ vector 를 이용하여 subcloning을 수행하였다. KpnI, BamHI을 동 시에 FLAG-CMV7.1 vector와 PCR amplicon을 표적으로 $37^{\circ} \mathrm{C}$ 에서 1 시간 반응을 수행하였다. 전기영동하여 얻은 플라스미드를 UltraClean ${ }^{\circledR} 15$ DNA Purification Kit (QIAGEN, Germany)를 사용하여 정제한 후, 실온에서 10분간 Mighty Mix kit (TaKaRa, Japan)를 이용하여 ligation 시켜주었다. 전기영동을 통해 단편 크기를 확인하고 sequencing을 의
뢰하여 염기서열을 확인하였다(Data not shown). 세포 배 양을 위해 HEK293T cell을 6-well plate에 DMEM (10\% FBS, Penicillin-Streptomycin $(100 \mathrm{U} / \mathrm{mL}))$ 을 well당 $0.7 \times 10^{6}$ cells을 분주하였다. $37^{\circ} \mathrm{C} 5 \% \mathrm{CO}_{2}$ 조건하에 세포 배양 후 $70 \sim 80 \%$ 가량 세포가 자라났을 때 $1.5 \mathrm{~mL}$ tube에 DMEM (serum free)을 $30 \mu \mathrm{L}$ 씩 분주하고 각 tube에 plasmid와 PolyJet(1:3 비율)을 첨가하여 transfection하였다. Total cell lysate 추출을 위해 PBS로 1회 세척 후 얼음 위에서 protease inhibitor cocktails (Roche, Germany)을 첨가한 RIPA cell lysis buffer $(150 \mathrm{mM} \mathrm{NaCl}, 1 \% \mathrm{NP}-40,1 \%$ sodium deoxycholate, $0.1 \% \mathrm{SDS}, 2 \mathrm{mM}$ EDTA, $50 \mathrm{mM}$ Tris- $\mathrm{HCl}, \mathrm{pH}$ 7.6)를 각 well에 $200 \mu \mathrm{L}$ 분주한 뒤 scraper를 이용하여 $1.5 \mathrm{~mL}$ tube 에 회수하였다. 회수한 cell lysate은 원심분리(12,000 x g, $\left.4^{\circ} \mathrm{C}, 5 \mathrm{~min}\right)$ 하여 상층액을 새 tube에 분리하여 다음 실험 에 사용하였다. Total cell lysate 상층액 $200 \mu \mathrm{L}$ 와 Protein $\mathrm{G}$ Sepharose ${ }^{\circledR} 4$ Fast Flow (GE Healthcare, USA) $20 \mu \mathrm{L}$ 를 $4{ }^{\circ} \mathrm{C}$ 에 서 약 1 시간 pre-clearing 시켜주었다. 원심분리하여 상층 액만을 분리해 낸 뒤 1차 항체 $1 \mu \mathrm{L} \mathrm{Myc} \mathrm{9E10} \mathrm{( \# M5546)}$ (Sigma-Aldrich, USA)를 첨가하여 $4{ }^{\circ} \mathrm{C}$ 조건에서 약 1 시간 반응 후, Protein G Sepharose ${ }^{\circledR}$ bead $20 \mu \mathrm{L}$ 를 $4{ }^{\circ} \mathrm{C}$ 에서 약 2 시 간 동안 면역침강(precipitation) 시킨다. 반응이 끝나면 원 심분리(13,000 x g, 5초)로 침전물을 모으고 lysis buffer를 이용해 3회 이상 세척 후 $5 \mathrm{x}$ sample buffer $(60 \mathrm{mM}$ Tris$\mathrm{HCl} \mathrm{pH}$ 6.8, 25\% glycerol, 2\% SDS, 0.1\% bromophenol blue, $2 \% \beta$-mercaptoethanol) $8 \mu \mathrm{L}$ 와 lysis buffer $32 \mu \mathrm{L}$ 첨가하여 $100{ }^{\circ} \mathrm{C}$ 에서 5 분간 긇인다. 원심분리 후 상층액만 취하여 SDS-PAGE 후 Immunoblot법으로 단백질을 분석하였다. HEK293T 세포에서 LRRK2 (WT)와 NOD2를 과발현시 켜 얻은 상층액(Total lysate)에 LRRK2 항체를 이용하여 LRRK2 단백질을 면역침강 후 western blot으로 Flag 항체 를 이용하여 단백질 결합을 확인하였다. Fig. 1에서 확인할 수 있듯이 대조군(1, 3번 lane)에서는 밴드가 보이지 않았 다. 세 번째 밴드가 희미한 것은 충분히 세척하지 못해 bead나 단백질 또는 항체에 비특이적으로 결합했을 것으 로 추정된다. 이를 통해 파킨슨병의 원인단백질로 잘 알 려진 LRRK2와 크론병의 원인단백질로 잘 알려진 NOD2 와의 결합을 확인할 수 있었다. 그리고 LRRK2 (Wild Type) 와 NOD2의 결합이 백인에게 흔한 대표적인 가족성 파킨 슨 환자 단일 돌연변이 $(\mathrm{G} 2019 \mathrm{~S})$ 와 결합력의 차이가 있는 지 확인해 보았다. Fig. 2에서 보는 바와 같이 Myc (MycLRRK2) 항체로 면역침강하고 Flag (Flag-NOD2) 항체로 immunoblot을 수행한 후 상대적인 band의 결합력을 분석 


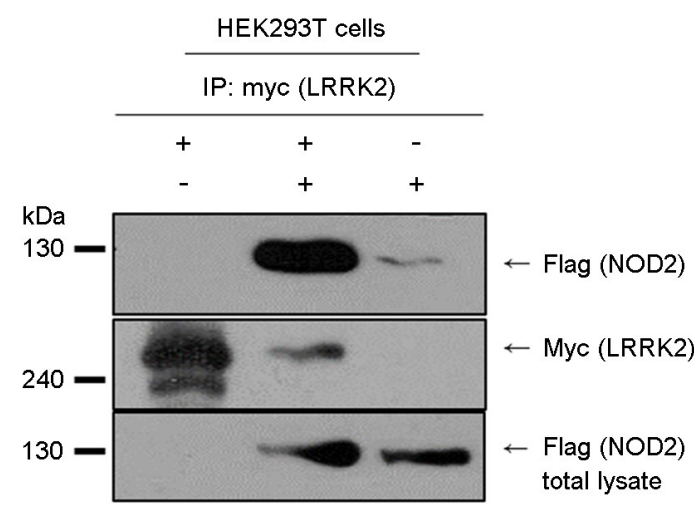

Fig. 1. LRRK2 physically interacts with NOD2. HEK293T cells were transiently transfected with Myc-tagged LRRK2 and Flagtagged NOD2. Total cell lysates were subjected to immunoprecipitation using anti-LRRK2. Immunocomplexs were resolved by SDSPAGE followed by immunoblotting against anti-NOD2 after $24 \mathrm{hr}$. Representative immunoblots from three independent experiments are shown.

하였는 데 wild type보다 G2019S와의 결합력이 더 강한 경향을 보였다. 본 연구에서는 LRRK2 유전자의 돌연변이 등으로 발병하는 파킨슨병과 장내 염증반응의 원인유전 자인 NOD2 유전자의 돌연변이가 유발하는 크론병과의 상호작용에 대해 LRRK2 단백질과 NOD2 단백질간의 상 호 결합을 한다는 사실을 확인할 수 있었다(Fig. 1). 또한 LRRK2 (WT), 그리고 LRRK2 (G2019S)의 NOD2와의 상대 적 결합강도에 차이가 있음을 확인하였다. 비슷한 실험을 수행한 많은 연구자들의 연구결과에서 확인(Rocha et al., 2015; Yan and Liu, 2017)할 수 있듯이 NOD2-LRRK2 단백 질간의 결합은 염증과 자가포식 등 질병 연관성에 영향 을 줄 수 있을 것으로 예상된다. 특히 결과 값의 흥미있 는 부분이 파킨슨병의 환자들의 대표적인 돌연변이로 알 려진 G2019S와 NOD2 유전자의 결합력이 LRRK2 (WT) 와 NOD2의 결합력보다 더욱 강하게 나타난다는 결과를 보였다. 이는 정상적인 LRRK2 (WT)는 p62 매개 자가포 식 현상이나 유비퀴틴 연계 프로테오좀 소멸경로를 통해 LRRK2 (WT)가 원활히 소멸되지만 돌연변이 G2019S는 소멸되는 메카니즘에 문제가 생겨 뇌에 축적되므로 남은 G2019S 돌연변이를 지닌 LRRK2가 NOD2 결합하여 강하 게 나타나는 것이 아닐까 생각한다. 결합력의 차이는 단 순한 상호 단백량의 차이만을 의미하는 것인지 LRRK2 kinase의 substrate로서 NOD2가 후보기질이 될 수 있는지 는 kinase assay를 통해서 확인해 보아야 할 것이다. 또한, LRRK2 유전자의 또 다른 돌연변이인 D1994A, G2385R들

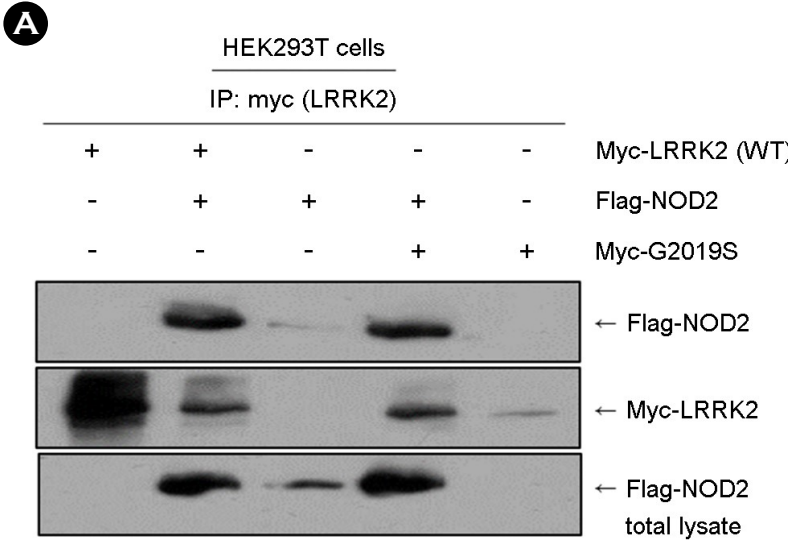

B $P<0.05$

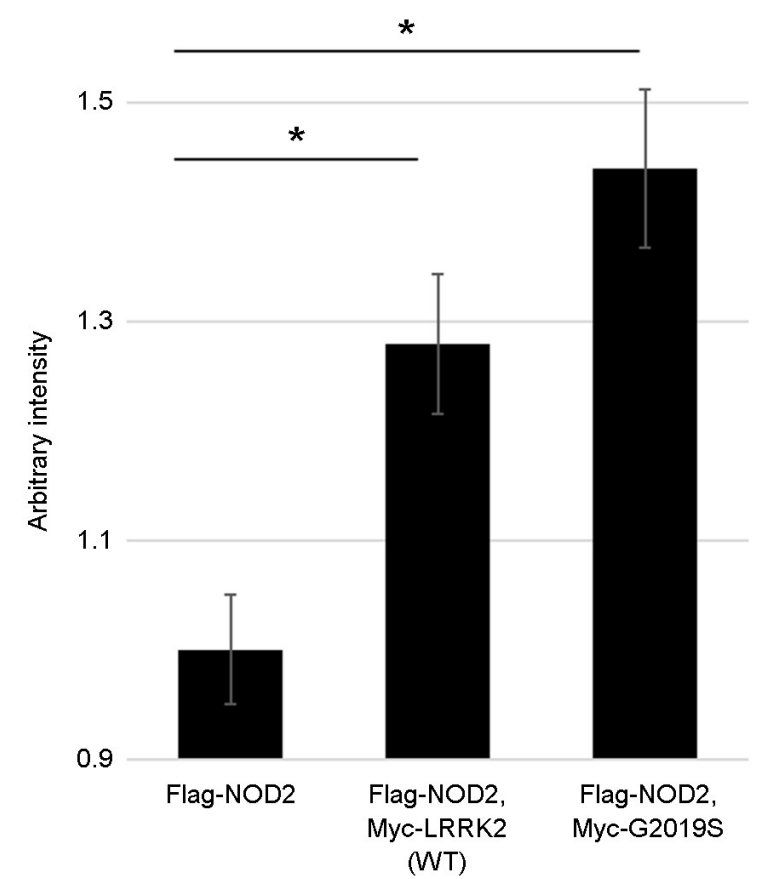

Fig. 2. LRRK2 mutant, G2019S has stronger interaction with NOD2, compared to those with LRRK2 (WT). (A) Similar experiments as Fig. 1 were performed with wild type LRRK2 or LRRK2 variant, G2019S in HEK293T cells. (B) Bar graph shows the relative binding intensity of NOD2 against LRRK2 vs. G2019S, which is normalized to LRRK2 WT $(P<0.05$, paired $t$-test $)$.

과 NOD2의 결합력의 차이가 앞선 결과들과 차이를 보이 는지 확인할 필요가 있다. 이는 돌연변이 단백질들은 제 거되지 않고 세포 내에서 축적되어 염증반응에 관여할 수 있고 돌연변이 매개성 대사작용의 이상으로 인해 질병 이 악화되거나 새로운 질병을 나타낼 수 있기 때문이다. 향후, NOD2의 길항제(agonist)인 N-glycolylated muramyl- 
dipeptide (gMDP)를 처리한 후 NOD2와 LRRK2 (WT), $\mathrm{NOD} 2$ 와 G2019S와의 결합력 차이가 있는지 확인할 필요 가 있다. 한편, 장내 세균과 뇌신경세포에 대한 연관성 연 구를 통해 크론병의 발병으로 야기되는 파킨슨병의 발병 확률이 증가할 수 있다는 사실이 NOD2와 LRRK2간 단백 질 결합의 시작점이 된다면, 분자생물학적인 상관관계를 통해 발병원인을 밝힐 수 있는 초입문이 될 것으로 기대 한다. 추가적으로 자가포식과 연관된 p62/SQSTM1, 자가 포식(autophagy)과 연관된 ATG 유전자 등이 어떻게 NOD2 단백질 발현에 영향을 주는지 연구함으로써 LRRK2와 $\mathrm{NOD} 2$ 의 관계에 p62/SQSTM1 매개 자가포식 및 유비퀴 틴매개 프로테오좀 사멸경로가 연관되어 있는지 밝힐 수 있는 기초를 마련할 수 있을 것으로 생각한다. 최근에 파 킨슨병과 미생물군-장-뇌 연결축에 대한 연구결과물에서 사람의 장과 뇌가 매우 밀접한 신호를 전달한다는 사실 을 알 수 있다. NOD2-p62/SQSTM1-LRRK2 연결축을 토대 로 장내 미생물군(microbiome)이 매개하는 퇴행성 뇌질환 과 크론병 또는 염증성 장질환이 이러한 단백질 결합분 자간의 신호전단에서 시작할 것으로 생각한다. 본 연구는 HEK293T 세포에서 일어난 결과임으로 반드시 신경세포 (cortical, hippocampal neuron)에서도 동일한 결과 값을 보이 는지 확인할 필요가 있으며 NOD2와 LRRK2가 서로 양 방향으로 영향을 주는지 많은 연구가 이뤄져야 할 것으 로 생각한다. NOD2-LRRK2 단백질 결합이 상호 병리생리 학적인 메카니즘에 기여함으로써 파킨슨병뿐만 아니라 크 론병의 이해를 도울 수 있을 것으로 기대한다.

\section{ACKNOWLEDGEMENT}

This study was supported by the Basic Science Research Program through the National Research Foundation of Korea (NRF) grant (http://ernd.nrf.re.kr) to S.P (NRF-2017R1D1A3B03029902), which was funded by the Ministry of Education.

\section{CONFLICT OF INTEREST}

No potential conflict of interest relevant to this article was reported.
Neurath MF, Ali RAR, Vavricka SR, Fiocchi C. Environmental triggers in IBD: a review of progress and evidence. Nat Rev Gastro Hepat. 2018. 15: 39.

Cryan JF, Dinan TG. Gut microbiota: Microbiota and neuroimmune signalling-Metchnikoff to microglia. Nat Rev Gastro Hepat. 2015. 12: 494-496.

Cummings JL. Depression and Parkinson's disease: a review. Am J of Psychiatry. 1992. 149: 443-454.

Gareau MG. Microbiota-gut-brain axis and cognitive function. Adv Exp Med Biol. 2014. 817: 357-371.

Park S, Ha SD, Coleman M, Meshkibaf S, Kim SO. p62/SQSTM1 enhances NOD2-mediated signaling and cytokine production through stabilizing NOD2 oligomerization. PLoS One. 2013. 8: e57138.

Park S, Han S, Choi I, Kim B, Park SP, Joe EH, Suh YH. Interplay between Leucine-Rich Repeat Kinase 2 (LRRK2) and p62/SQSTM-1 in Selective Autophagy. PLoS One. 2016. 11: e0163029.

Rajput A, Dickson DW, Robinson CA, Ross OA, Daechsel JC, Lincoln SJ, Cobb SA, Rajput ML, Farrer MJ. Parkinsonism, Lrrk2 G2019S, and tau neuropathology. Neurol. 2006. 67: 1506-1508.

Rocha JD, Schlossmacher MG, Philpott DJ. LRRK2 and Nod2 promote lysozyme sorting in Paneth cells. Nat Immunol. 2015. 16: 898-900.

Van Limbergen J, Wilson DC, Satsangi J. The genetics of Crohn's disease. Annu Rev Genom Hum Genet. 2009. 10: 89-116.

Yan R, Liu Z. LRRK2 enhances Nod1/2-mediated inflammatory cytokine production by promoting Rip2 phosphorylation. Protein Cell. 2017. 8: 55-66.

https://doi.org/10.15616/BSL.2020.26.1.47

Cite this article as: Jung JA, Park S. The Physical Interaction between Nucleotide-Binding Oligomerization Domain Containing 2 and Leucine-Rich Repeat Kinase 2. Biomedical Science Letters. 2020. 26: 47-50.

\section{REFERENCES}

Ananthakrishnan AN, Bernstein CN, Iliopoulos D, Macpherson A, 